\title{
THE PREVALENCE OF EXTENDED SPECTRUM $\beta$-LACTAMASE (ESBL) PRODUCING GUT BACTERIAL FLORA AMONG PATIENTS IN DR. SOETOMO HOSPITAL AND PRIMARY HEALTH CENTER IN SURABAYA
}

\author{
Dian Neni Naelasari ${ }^{1}$, Eko Budi Koendhori ${ }^{2}$, Linda Dewanti ${ }^{3}$, Sulistiawati ${ }^{3}$, Rosantia Sarassari ${ }^{3}$, K. Kuntaman $^{2,4}$ \\ ${ }^{1}$ Master Program in Basic Medical Sciences, Faculty of Medicine, ${ }^{2}$ Department of Microbiology, Faculty of Medicine, \\ Universitas Airlangga/Dr Soetomo Hospital, Surabaya, ${ }^{3}$ Department of Public Health, Faculty of Medicine, ${ }^{4}$ Institute \\ of Tropical Disease, Universitas Airlangga, Surabaya, Indonesia
}

\section{ABSTRACT}

The extended-spectrum $\beta$-lactamase (ESBL) producer bacteria until now are mostly identified in hospital environment. The aim of this study was to analyze the prevalence of ESBL-producing gut flora and distribution of ESBL encoding genes between hospitalized patients in Tropical Wards of Dr. Soetomo Hospital and patients from a primary health center (PHC) as community environment in Surabaya. Thirty rectal swab samples from patients of Dr. Soetomo Hospital and of PHC (60 samples in total) were collected for this study. Samples were screened in MacConkey agar supplemented with $2 \mathrm{mg} / \mathrm{L}$ of cefotaxim, incubated at $37^{\circ} \mathrm{C}$ for 24 hours. Furthermore, the growing colony were confirmed with Disk Diffusion Synergy test (DDST) for diagnosis of ESBL producer. The identified ESBL producers were then identified the bacteria species by biochemical method. ESBL gene were detected by PCR with specific primers. The results showed that there was no difference in the positive number of ESBL-producing gut bacterial flora between patients of Dr. Soetomo Hospital, 25/30 (83.3\%) and PHC, 11/30 (36.7\%) (p=1). The pattern of ESBL gene distributions among samples from the hospital showed that SHV was 12\%, TEM was 36\%, and CTX-M was 80\%, and from PHC were SHV $18.2 \%$, TEM $27.3 \%$ and CTX-M 81.8\%. Statistical analysis showed that the pattern was not significantly different among hospitals and PHC samples as shown by SHV gene $(p=0.631)$, TEM $(p=0.715)$, and CTX $-M(p=1)$. From each ESBL gene, the dominant genes that found producing ESBL were the CTX-M genes followed by TEM and SHV genes. The prevalence of ESBL producers in intestinal flora of both the hospital $(83,3 \%)$ and the PHC (36,7\%) was very high. There was no significant difference between the prevalence of ESBL producer in gut flora of hospitalized patients compared to PHC. We also found other patterns of ESBL gene combinations in the hospital. The patterns are SHV+CTX-M genes, TEM+CTX-M, SHV+TEM+CTX-M genes, and in PHC, the combination pattern are $S H V+C T X-M, T E M+C T X-M$.

Keywords: Gut flora; ESBL; Dr. Soetomo Hospital; Primary Health Center (PHC)

\section{ABSTRAK}

Bakteri penghasil spektrum $\beta$-laktamase (ESBL) yang meluas sebagian besar diidentifikasi di lingkungan rumah sakit. Penelitian ini bertujuan untuk menganalisis perbandingan prevalensi dan distribusi gen ESBL pada bakteri flora usus pada pasien di RSUD Dr. Soetomo ruang tropik dan Puskesmas " $X$ " di Surabaya. Sampel penelitian sebanyak 60 sampel terdiri dari 30 sampel pasien rumah sakit dan 30 sampel pasien puskesmas diambil dari hasil swab rektum pada masing-masing lokasi. Sampel ditanam di media selektif MacConkey dengan penambahan sefotaksim $2 \mathrm{mg} / \mathrm{L}$, dan diinkubasi selama 24 jam pada suhu $37^{\circ} \mathrm{C}$. Koloni yang tumbuh didiagnosis dengan pemeriksaan biokimiawi, kemudian dilanjutkan dengan deteksi fenotipik dengan uji Disk Diffusion Synergy test (DDST) dan genotipik menggunakan PCR untuk mendeteksi gen ESBL. Hasil: Hasil pemeriksaan menunjukkan tidak terdapat perbedaan jumlah positif bakteri ESBL flora usus antara pasien rumah sakit Dr. Soetomo, yaitu 25/30 (83,3\%) dan pasien puskesmas, yaitu 11/30 (36,7\%) (p=1). Pola distribusi gen ESBL pada rumah sakit ditemukan gen SHV (12\%), TEM (36\%), dan CTX-M (80\%), dan di puskesmas ditemukan gen SHV (18,2\%), TEM (27,3\%) dan CTX-M (81.8\%). Hasil analisis menunjukkan bahwa tidak terdapat perbedaan pola prevalensi dan distribusi gen pada rumah sakit dan puskesmas gen $S H V(P=0,631)$, TEM $(P=0,715)$, dan gen CTX-M $(P=1)$. Dari gen ESBL yang diteliti (gen SHV, TEM, dan CTX-M) ditemukan bahwa, gen CTX-M adalah gen yang dominan menghasilkan bakteri ESBL, diikuti gen TEM dan SHV. Kesimpulan: Prevalensi gen ESBL pada bakteri usus baik di rumah sakit maupun Puskesmas sangat tinggi. Tidak ada perbedaan prevalensi di antara gen ESBL flora usus pasien rumah sakit di banding Puskesmas. Ditemukan pola kombinasi gen ESBL pada rumah sakit, kombinasi gen SHV+CTX-M, $T E M+C T X-M$, SHV+TEM+CTX-M dan puskesmas, kombinasi gen SHV+CTX-M, gen TEM+CTX-M.

Kata kunci: Flora usus; ESBL; Rumah Sakit Dr. Soetomo; Puskesmas X

Correspondence: K. Kuntaman, Faculty of Medicine, Universitas Airlangga, Jl. Dr. Moestopo 47 Surabaya, Indonesia. E-mail. kuntaman@fk.unair.ac.id

pISSN:2355-8393 • eISSN: 2599-056x • doi: http://dx.doi.org/10.20473/fmi.v54i4.10708

- Fol Med Indones. 2018;54:256-262 • Received 22 Sep $2017 \bullet$ Accepted 22 Mar 2018

- Open access under CC-BY-NC-SA license • Available at https://e-journal.unair.ac.id/FMI/ 


\section{INTRODUCTION}

The effect of antibiotic therapy on clinical infection cases may have an impact on commensal bacteria present in humans, such as intestinal flora. The effect of antibiotic use may lead to increased populations of resistant bacteria to antibiotic in human intestine. The pattern of bacterial populations in the body depends on exposure to the type of antibiotic used, antibiotic action, and the level of resistance present in the community (Jernberg et al 2010).

Nowadays, the most important of bacterial resistance to antibiotics is Extended-spectrum $\beta$-lactamase (ESBL) bacteria. ESBL is a $\beta$-lactamase enzyme that may induce bacterial resistance to penicillin, 1, 2 and 3 cephalosporins generation, and aztreonam (but not to cephamine and carbapenem) by hydrolyzing antibiotics, which can be inhibited by $\beta$-lactamase inhibitors, such as clavulanic acid (Peterson \& Bonomo 2005). ESBL is produced by gram-negative bacteria, one of which is the Enterobacteriaceae family which is one of the normal flora of the intestine. These bacteria have been reported to be resistant to $\beta$-lactam antibiotics. The bacteria Enterobacteriaceae is one of the main causes of bacterial infections in hospitals, site of treatments, or in the community (Shakil \& Khan 2010).

During 2008 in Thailand, the bacteria of Enterobacteriaceae was identified in about $60 \%$ of the stools of healthy individuals in the community (Sasaki et al 2010). In 2002, ESBL-producing bacteria from rectal swabs were found in $0.9 \%$ among community health centers (Severin 2010). The spread of microorganism resistance easily occurs among strains and even among species, since ESBL encoding gene is located in the plasmid, which facilitates the transfer of bacterial ESBL genes (Colodner \& Raz 2005). There are three types of the ESBL gene group: sulfhydryl variable (SHV), type of Temoneira enzyme (TEM), and cefotaximase-munich (CTX-M) (Peterson \& Bonomo 2005, Pitout \& Kevin 2008). In the UK, there are two studies on the widespread of ESBL-producing bacteria. The first study, from York, bacterial member of Enterobacteriaceae was found to produce CTX-M genes in community and hospitalized patients. A second study was conducted by Woodford et al. who examined 291 samples and found Escherichia coli that produced the CTX-M gene (Kumar and Babu, 2013). A research in Indonesia found the prevalence of CTX-M gene was about $94.5 \%$ (Severin 2010).

In hospitals and primary health centers, the spread of ESBL-producing bacteria poses a major challenge in reducing the spread of multi-resistant bacteria. This study discloses important information about increasing of ESBL-producing gut flora in both hospital and primary health center (PHC) to explore the spread of ESBL producing bacterial and planning the program for controlling bacterial resistance. This study aimed to determine the pattern of ESBL gene distribution in Tropical Wards of Dr. Soetomo Hospital and in PHC in Surabaya.

\section{MATERIALS AND METHODS}

The study was conducted from April to July 2017 at Department of Clinical Microbiology, Dr. Soetomo Hospital, Surabaya, and Institute of Tropical Disease, Universitas Airlangga. All rectal swab samples were collected from patients in tropical ward of Dr. Soetomo Hospital and PHC. Total sampel was 60 rectal swab samples consisted of 30 samples from the tropical ward of Dr. Soetomo Hospital taken with consecutive sampling technique and met the inclusion and exclusion criteria; and 30 samples from the PHC taken with systematic random sampling technique. Samples from the PHC was randomly selected from the samples of previous study (Dewanti et al 2016). The samples were grown in MacConkey selective media supplemented with cefotaxime of $2 \mathrm{mg} / \mathrm{L}$, incubated for 18-24 hours at $37^{\circ} \mathrm{C}$ (Sasaki et al 2010). The bacteria which were able to grow on that medium was suspected as ESBL producing bacteria.

ESBL confirmation was perfomed using Double Disk Synergy Test (DDST). The antibiotic disks used for DDST included Cefotaxime (CTX), Ceftazidime (CAZ), Ceftriaxone (CRO), and Astreonam (ATM) discs. Each disc contained $30 \mu \mathrm{g}$ disks, and Amoxicillin-clavulanic acid (AMC) $(30 / 10 \mu \mathrm{g}$ disk). The results were positive if an inhibitory zone or synergy occurs between one disc and AMC disk (Dalela 2012, Dhara et al 2012). The species were identified using colonial morphology on Mac-Conkey selective agar plates, followed by bio-chemical examination, other tests such as triple sugar iron (TSI), indole, methyl red (MR), voges proskauer (VP), citrate, and motility test (Tille 2014). Genotypic identification by using PCR amplification, with the primers were SHV-F, 5'GGTTATGCGTTATATTCGCC-3', SHV-R, 5'TTAGGTTGCCAGTGCT-3' with amplicon size of 867 bp, PCR conditions of 1 cycle of $5 \mathrm{~min}$ at $96^{\circ} \mathrm{C} ; 35$ cycles of $1 \mathrm{~min}$ at $96^{\circ} \mathrm{C}$ (denaturation), $1 \mathrm{~min}$ at $60 \mathrm{oC}$, $1 \mathrm{~min}$ at $72{ }^{\circ} \mathrm{C}$ (annealing); 1 cycle of $10 \mathrm{~min}$ at $72{ }^{\circ} \mathrm{C}$ (extension). TEM-F primers, 5'-ATGAGTATTCAACA TTTCCG-3', TEM-R, 5'-CTGACAGTTACCAATGCT TA-3' with amplicon size of $867 \mathrm{bp}$, PCR conditions of 1 cycle of $5 \mathrm{~min}$ at $96^{\circ} \mathrm{C} ; 35$ cycles of $1 \mathrm{~min}$ at $96^{\circ} \mathrm{C}$ (denaturation); $1 \mathrm{~min}$ at $60^{\circ} \mathrm{C}$ (annealing); $1 \mathrm{~min}$ at $72{ }^{\circ} \mathrm{C}$; 1 cycle of $10 \mathrm{~min}$ at $72^{\circ} \mathrm{C}$ (extension). CTX-MF 5'- 
ATGTGCAGYACCAGTAARGT-3 primer and CTXM-R 5' TGGGTRAARTARCTSACCAGA 3' with amplicon size of $593 \mathrm{bp}, \mathrm{PCR}$ conditions of 1 cycle of 7 min at $94^{\circ} \mathrm{C} ; 35$ cycles of $50 \mathrm{sec}$ at $94{ }^{\circ} \mathrm{C}$ (denaturation), $40 \mathrm{sec}$ at $52^{\circ} \mathrm{C}$ (annealing), $1 \mathrm{~min}$ at $72^{\circ} \mathrm{C} ; 1$ cycle of $10 \mathrm{~min}$ at $72^{\circ} \mathrm{C}$ (extension) (Ferreira et al 2011). Data were statistically analyzed by Fisher's Exact test with SPSS version 23 program.

\section{RESULTS}

Characteristic of the subjects showed that the highest percentage was females as many as 25/30 subjects (83.3\%) from the hospital, and 19/30 samples (63.3\%) from PHC. There was no significant difference in sex distribution between samples from hospital and PHC $(\mathrm{p}=0.143)$. Based on age characteristics, we took all age groups categories obtained from sampling sites. The highest percentage from the hospital was productive age (15-60 years) those were $20 / 30$ patients $(66.7 \%)$ from the hospital, whereas, the highest percentage from the PHC, was younger age ( $<15$ years) those were $14 / 30$ patients $(53.3 \%)$. There was no significant difference in age distribution between samples from hospital and PHC $(\mathrm{p}=0.108)$.

Data on the use of antibiotic in hospital showed that 21 out of 30 patients $(70 \%)$ used antibiotics, while in PHC there was no patient used antibiotics $(0 \%)$. There was a significant difference in antibiotic usage patterns between the hospital and PHC $(\mathrm{p}=0.000)$. The prevalence of ESBL producing gut flora (after confirmed by DDST) in the hospital and PHC was 25/30 (83.3\%) and $11 / 30(36.7 \%)$ respectively. Genotyping ESBL encoding genes by using PCR found 22 samples from the hospital and 10 samples from PHC containing ESBL encoding genes. There was no significant differences on the distributions of ESBL encoding gene between the hospital and PHC samples $(\mathrm{p}=1)$. ESBL encoding genes were identified in samples from the hospital and 1 samples from PHC (Tabel 1).

\section{DISCUSSION}

General characteristics by age and sex indicate no risk of ESBL gene in the feces, which is usually reported as rare. Other studies found that the distribution of ESBL was equally distributed in all age groups (Nakayama et al 2012, Yuwono 2011). There was a significant difference in antibiotic usage patterns between hospitals and PHC. In this study the use or not using of antibiotics showed differences in the prevalence and distribution genes. Although there was no antibiotic use in PHC, the frequency of ESBL resistance was high. It cannot be explained the role of antibiotic use against the prevalence and distribution of ESBL genes in this study. There may be other contributing factors, such as the spread of ESBL-producing bacteria, between PHC patients and hospital patients, $\mathrm{PHC}$ patients and the community, between individuals in the community, or the food chain cycles in the environment. Hilty et al (2012) found a dynamic spread in patient families, patients with patients and hospitals with communities. Another study conducted by Imasari et al (2017) showed the ESBL gene have spread among animals (dairy cows) $(72 \%)$ and humans $(79.1 \%)$ (people around farms), this spread may occur through direct contact or indirectly. The results of this study were similar to those of Sarassari (2017) that found $98 \%$ of ESBL positive intestinal flora in medical student community with no antibiotic use.

Table 1. Distribution of ESBL (+) and genotyping of ESBL gene by PCR

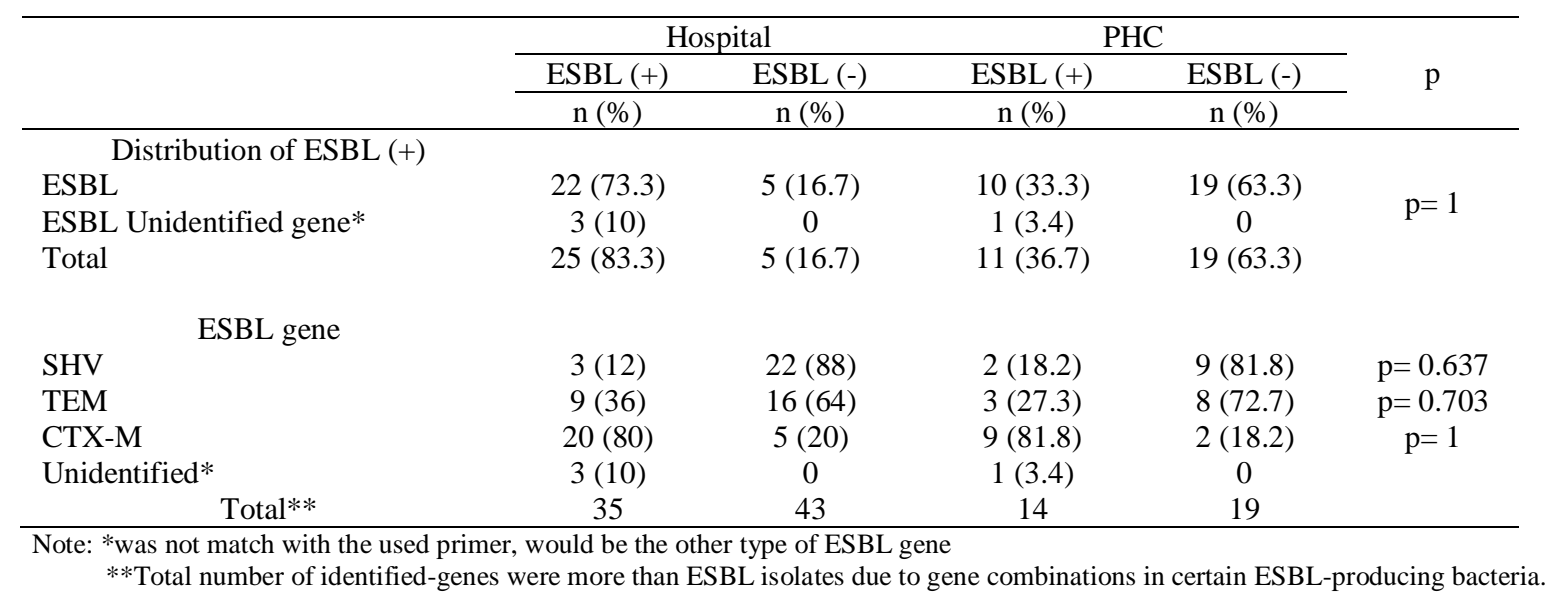


Table 2. Combination of ESBL genes in ESBL-producing bacteria

\begin{tabular}{lcc}
\hline \multicolumn{1}{c}{ Combination of ESBL gene } & $\begin{array}{c}\text { Hospital } \\
\mathrm{n}(\%)\end{array}$ & $\mathrm{PHC}$ \\
$\mathrm{n}(\%)$
\end{tabular}

Table 3. Identifications of species and distribution pattern of ESBL-producing gut bacteria

\begin{tabular}{lccc}
\hline \multirow{2}{*}{ Gut bacteria } & Hospital & Primary Health Centre & \multirow{2}{*}{$\mathrm{p}$} \\
\cline { 2 - 3 } & $\mathrm{n}(\%)=25$ & $\mathrm{n}(\%)=11$ & \\
\hline Escherichia coli & $20(80)$ & $8(72.7)$ & \\
Klebsiella pneumoniae & $2(8)$ & $3(27.3)$ & \\
Pseudomonas aeruginosa & $2(8)$ & 0 & \\
Enterobacter aerogenes & $1(4)$ & 0 & \\
\cline { 1 - 3 } Total & 25 & 11 & \\
\hline
\end{tabular}

In this study, the CTX-M gene pattern was more dominant than the TEM and SHV genes. In the hospital, CTX-M gene was found in 20/25 (80\%), while in the PHC the CTX-M gene was $9 / 11$ (81.8\%) (Table 1). The results of this study were similar to that of a study conducted by Severin (2010) in Escherichia coli who found that CTX-M gene (94.5\%) was higher than SHV $(65.3 \%)$ genes and TEM-type ESBLs were not detected in any of the isolates. Feces may play a role in the spread of Enterobacteriaceae bacteria in hospitals and the environment. The prevalence of ESBL-producing bacteria has been reported in Asia. In Indian and Chinese populations, ESBL distribution in the feces may be around $10 \%$ (Hawkey 2008). In Lebanese infant stools CTX-M genes was dound in $47.2 \%$, TEM was $20.7 \%$, and SHV was $1.9 \%$. The study also found a CTX-M gene $(54.7 \%)$ with two or three types of genes (blaCTX-M-9, blaCTX-M-15, and blaCTX-M-2) (Moustafa et al 2015).

Examination of healthy people in Thailand showed that $65.7 \%$ of feces detected containing ESBL-producing Enterobacteriaceae carried the CTX-M gene, among them CTX-M-9 $60.6 \%$ and CTX-M-1 gene was 38,7\% (Luvsanharav et al 2012). The transmission of ESBL encoding Enterobacteriaceae in 112 healthy children, found 3 (2.6\%) Escherichia coli producing ESBL (CTX-M-1, TEM-52 and SHV-12) (Guimaraes et al 2009). Asymptomatic colonization of the intestine with ESBL-producing Enterobacteriaceae is considered a prerequisite for infection. This increase is related to ESBL dominance with CTX-M type enzyme. The ESBL coding gene is easy to move, just like ISEcp1 (Kumar \& Babuz, 2013). ISEcp1 insertion is a transposable element that may combine and mobilize fragmentation of DNA flanking through a final transposition mechanism, which may experimentally mediate the capture of blaCTX-M genes from the Kluyvera spp chromosome and may facilitate inter-replication in host bacteria such as Escherichia coli (Bonnet 2004, Rossolini et al 2008).

This study found a combined phenomenon of ESBL gene in some strains of bacteria. The most combination and the most dominant genes were found in hospital isolates, ie TEM + CTX-M genes of 6 (24\%), whereas in PHC, the TEM + CTX-M genes as many as 2 $(18,2 \%)$ (Table 2$)$. In this study only one strain carrying the TEM+SHV+CTX-M (4\%) genes was identified in the hospital. Results of outpatient and inpatient study in Japan showed a combination pattern of TEM/SHV + CTX-M for three bacterial agents, such as E. coli 120 (53.8\%), K. pneumoniae 24 (77.4\%) and Proteus mirabilis $8(66.7 \%)$ (Chong et al 2013). Transmission of ESBL producing Enterobacteriaceae in 112 healthy children showed $3(2.6 \%)$ E. coli producing ESBL (CTX-M-1, TEM-52 and SHV-12) (Guimaraes et al 2009). Conjugative plasmids play an important role in increasing the spread of ESBL through the transfer of resistance genes to other bacteria in the hospital as well as the environment.

ESBL is mostly encoded by plasmids, some of which are known to be large (up to $100 \mathrm{~kb}$ or more). Large plasmids are also found to encode the CTX-M gene, which is an IncFII plasmid type that may insert or encode other antibiotic resistance genes that may be transferred from strain to strain and between bacterial species (Jarlier et al 1988, Rao 2012). The plasmid type 
of IncFII is the most common replica and detected in 20 $(58.8 \%)$ (10 E. coli and $10 \mathrm{~K}$. pneumoniae) of 34 isolates (Rakotonirina et al 2013). The CTX-M gene may carry more than one replicon and may associate with the OXA, TEM and aac- (6) genes in the IncFII plasmid (Carattolli 2009).

The research has found that the predominant ESBLproducing bacteria were $E$. coli $(80 \%)$ and $K$. pneumoniae (8\%) from the hospital and E. coli $(72.7 \%)$ and $K$. pneumoniae $(27.3 \%)$ from the PHC. Analysis of bacterial distribution showed significant difference between the distribution in the hospital and PHC. Other bacterias were also found in this study, such as Enterobacter aerogenes and Pseudomonas aeruginosa (Table 3). A research in Surabaya (2017) found ESBLproducing gut flora in Tropic infection patients, which were E. coli $(66 \%), \quad K$. pneumoniae (6.6\%), and Enterobacter aerogenes $(3.3 \%)$, and in community were E. coli $(71 \%)$, K. pneumoniae $(10 \%)$, Enterobacter aerogenes $(0 \%)$ from rectal swab patients. (Sarassari 2017). The results of this study were an improvement from a previous one conducted by Kuntaman et al (2016) in Dr. Soetomo Hospital, Surabaya, on the prevalence of ESBL-producing bacteria where $E$. coli $(62 \%)$ and K. pneumoniae (45.1\%).

Other studies have shown that Escherichia coli, which is an intestinal flora, was resistant to cefotaxime in hospitalized patients (at least 5 days of hospitalization), but on the first day of hospitalization. The bacteria are thought to come from the community (Amrin 2001). Cross-transmission may occur in an environment such as water, soil, and plants, where the exchange of genetic material between bacteria and/or environmental origin occurs. Other studies have demonstrated poor access to drinking water, poverty and high population density as a very efficient risk factor for the spread of ESBLproducing bacteria, such as disease through fecal-oral transmission. Aquatic ecosystems, such as water or waste pollution (Woerther et al 2013) and well water (Amaya et al 2012), allow the spread of ESBL strains from animals to humans through the food industry (Kluytmans et al 2013), and pets (Poirel et al 2013).

\section{CONCLUSION}

The ESBL carrier rate of patients in hospital and PHC was high and not significantly different, respectively were $83.3 \%$ and $36.7 \%$. The ESBL gene was dominated by CTX-M, then, at a lower level, TEM and SHV. This findings indicated that there has been a uniform distribution between hospital and PHC. It cannot be explained here whether ESBL-producing bacteria moved from hospital to PHC or from PHC to hospital.
We found other patterns of ESBL gene combinations in the hospital of SHV+CTX-M genes, TEM+CTX-M, $\mathrm{SHV}+\mathrm{TEM}+\mathrm{CTX}-\mathrm{M}$ genes and PHC, the combination pattern of SHV+CTX-M, TEM+CTX-M. Appropriate infection control practices are essential to prevent the spread and outbreak of ESBL-producing bacteria. There is no doubt that ESBL will become increasingly complex and diverse and its detection becomes increasingly challenging for clinical microbiology laboratories. It is recommended to undergo studies with larger quantities of samples and in various PHC and to find out the cause of increase of ESBL prevalence in PHC.

\section{REFERENCES}

Amaya E, Reyes D, Paniagua M, Calderon S, Rashid MU, Colque P, Kuhn I, Mollby R, Weintraub A, Nord CE (2012). Antibiotic resistance patterns of Escherichia coli isolates from different aquatic environmental sources in Leon, Nicaragua. Clin. Microbiol. Infect 18, E347-E354

Amrin (2001). Antimicrobial resistance in Indonesia: Prevalance and prevention. The Collaboration research Indonesia and The Netherlands. Not yet published.

Bonnet R (2014). Growing group of extended-spectrum beta-lactamases: the CTX-M enzymes. Antimicrob. Agents Chemother 48, 1-14

Carattoli A (2009). Resistance plasmid families in Enterobacteriaceae. Antimicrob Agents Chemother 53, 2227-2238

Chong Y, Shimoda S, Yakushiji H, Ito Y, Miyamoto T, Kamimura T, Shimono N, Akashi K (2013). Community spread of extended-spectrum beta-lactamase-producing Escherichia coli, Klebsiella pneumoniae and Proteus mirabilis: A long-term study in Japan. Journal of Medical Microbiology 62 (PART7), 1038-1043

Colodner R, Raz R (2005). Extended-Spectrum BetaLactamase: The end of cephalosporins. IMAJ 7, 336338

Dalela G (2012). Prevalence of extended spectrum betalactamase (ESBL) producers among gram-negative bacilli from various clinical isolates in a tertiary care hospital at Jhalawar, Rajasthan, India. J ClinDiag Research 6, 182-187

Dewanti L, Sulistiawati, M. Qiptiah, U Hadi, H. Paraton, K. Kuntaman (2016). Survey penggunaan antibiotik dan mikroba resistensi di Puskesmas di Surabaya. Survey Oleh Direktorat Jenderal Pelayanan Kesehatan Kementerian Kesehatan Republik Indonesia. Unpublished.

Dhara M, Disha P, Sachin P, Manisha J, Seema B, Vegad MM. (2012). Comparison of various methods for the detection of extended spectrum betalactamases in Klebsiella pneumoniae isolated from 
neonatal intensive care unit. National J Med Res 2, 348-53

Ferreira CM, Ferreira WA, Almeida NC, Naveca FG, Barbosa Md (2011). Extended spectrum beta lactamase producing bacteri isolated from hematologic patients in manaus, state of Amazonas, Brazil. Brazilian Journal of Microbiology. 42: 1076-1084

Guimaraes B, Barreto A, Radhouani H, Figueiredo N, Gaspar E, Rodrigues J, Torres C, Igrejas G, Poeta P (2009). Genetic detection of extended-spectrum betalactamase-containing Escherichia coli isolates and vancomycin-resistant enterococci in fecal samples of healthy children. Microb Drug Resist 15, 211-216

Hawkey PM (2008). Prevalence and clonality of extended-spectrum b-lactamases in Asia. Clin Microbiol Infect 14, 159-65

Hilty M, Betsch BY, Bögli-Stuber, et al (2012) Transmission dynamics of extended-spectrum-lactamaseproducing enterobacteriaceae in the tertiary care hospital and the household setting, Clinical Infectious Diseases 55, 967-975

Imasari T, Wiwik T, Wasito EB, K Kuntaman (2017). The prevalence and patterns of gene among bacterial gut flora of dairy cows and people around farm in Surabaya. Journal Veteriner Udayana

Jarlier V, Nicolas MH, Fournier G, Philippon A (1988). Extended broad-spectrum beta lactamases conferring transferable resistance to newer beta lactam agents in Enterobacteriaceae: hospital prevalance and susceptibility patterns. Rev. Infect. Dis 10, 867-878

Jernberg C, Löfmark S, Edlund C, Jansson JK (2010). Long-term impacts of antibiotic exposure on the human intestinal microbiota. Microbiology 156, 32163223

Kluytmans JA, Overdevest IT, Willemsen I, Kluytmansvan den Bergh MF, van der Zwaluw K, Heck M, Rijnsburger M, Vandenbroucke-Grauls CM, Savelkoul PH, Johnston BD, Gordon D, Johnson JR (2013). Extended-spectrum beta-lactamase-producing Escherichia coli from retail chicken meat and humans: comparison of strains, plasmids, resistance genes, and virulence factors. Clin. Infect. Dis. 56:478 - 487.

Kumar AV, Babuz R (2013). Fecal carriage of extended-spectrum beta-lactamase producing enterobacteriaceae. J. Medical Microbiology \& Diagnosis, 2:3.

Kuntaman K, Hadi U, Setiawan F, Koendori EB, Rusli M, Santosaningsih D, Severin J, Verbrugh HA (2016). Prevalence of methicillin resistant Staphylococcus aureus from nose and throat of patients on admission to medical wards of Dr. Soetomo Hospital, Surabaya, Indonesia. Southeast Asian J Trop Med Public Health $47,66-70$

Moustafa SH, Anwar MF, Moustafa FA, Hussein KA (2015). Multidrug-resistant ESBL-producing Enterobacteriaceae and associated risk factors in community infants in Lebanon. J Infect Dev Ctries, 947-955
Nakayama S, Tribuddharat C, Prombhul S, Shimuta K, Srifuengfung S, Unemo M, Ohnishi M (2012). Molecular analyses of TEM genes and their corresponding penicillinase-producing Neisseria gonorrhoeae isolates in Bangkok, Thailand. Antimicrob Agents Chemother 56, 916-20

Peterson DL, Bonomo RA (2005). Extended spectrum beta-lactamases: A clinical update. J. Clinical Microbiology Reviews. American Society for Microbiology 18, 657-686

Pitout JD, Kevin BL (2008). Extended-spectrum betalactamase-producing Enterobacteriaceae: An emerging public-healt concern. Lancet Infect Dis 8, 159-161

Poirel L, Nordmann P, Ducroz S, Boulouis HJ, Arne P, Millemann Y. 2013. Extended-spectrum beta-lactamase CTX-M-15-producing Kleb-siella pneumoniae of sequence type ST274 in companion animals. Antimicrob. Agents Chemother 57, 2372-2375

Rao S. 2012. CTX-M beta-lactamases. Available from www.microrao.com/micronotes/pg/ctx-m-beta-lactamases.pdf. Accessed Feb 22, 2017

Rakotonirina H C, Garin B, Randrianirina F, Vincent R, Talarmin A, and Guillaume A (2013). Molecular characterization of multidrug-resistant extendedspectrum beta-lactamase-producing Enterobacteriaceae isolated in Antananarivo, Madagascar. BMC Microbiologi. 13-85

Rossolini G M, D’Andrea M M, C. Mugnaioli (2008). The spread of CTX-M-type extended-spectrum blactamases. Journal complication. European Society of Clinical Microbiology and Infectious Diseases, CMI 14, 33-41

Sasaki T, Hirai I, Niki M, Nakamura Tatsuya, Komalamisra C, Maipanich W, Kusolsuk T, Sanguankiat S, Pubampen S, and Yamamoto Y. 2010. High prevalence of CTX-M b-lactamase-producing Enterobacteriaceae in stool specimens obtained from healthy individuals in Thailand. J. Antimicrob Chemother 65, 666-668

Sarassari R (2017). Perbandingan pola fenotipik dan genotipik bakteri penghasil ESBL dari flora usus pasien di ICU, Rawat Inap Tropik Infeksi, Dan Populasi Di Komunitas. An unpublished thesis. Surabaya, Faculty of Medicine, Universitas Airlangga

Severin, JA (2010). Molecular characterization of extended-spectrum beta-lactamases in clinical Escherichia coli and Klebsiella pneumonia isolates from Surabaya, Indonesia. J. Antimicrob Chemother 65, 465-469.

Shakil S, Khan AU (2010). Infected foot ulcers in male and female diabetic patients: a clinico-bioinformative study. Licensee BioMed Central Ltd. India, Aligarh Muslim University

Tille PM (2014). Bailey \& Scott's diagnostic microbiology. 13th ed. Mosby, Inc., an affiliate of 
Elsevier Inc. Missouri, Riverport Lane St. Louis, $\mathrm{p}$ 63043.

Woerther PL, Burdet C, Elisabeth C, Antoine A (2013). Trends in human fecal carriage of extended-spectrum lactamases in the community: Toward the globalization of CTX-M. Clinical Microbiology Reviews, 744-758

Yuwono J (2011). Prevalensi gen TEM pada extended spectrum beta lactamase producing enterobactericeae. Jurnal Kedokteran dan Kesehatan 43, 3098-3102 